\title{
EPICUREUS, ESTOICOS E A QUESTÃO DA RESSURREIÇÃO NO LIVRO DE ATOS DO APÓSTOLOS
}

Epicurios, Stoic And The Question Of Resurrection In The Book Of Acts Of The Apostles

Francisco Eduardo de Oliveira ${ }^{1}$

\section{RESUMO}

Este artigo tem por finalidade apresentar possíveis motivos pelos quais os filósofos estoicos e epicúreos não aceitaram a noção de ressurreição apresentado no discurso do apóstolo Paulo, proferido no areópago e descrito por Lucas no livro de Atos dos Apóstolos.

PALAVRAS-CHAVE: Estoicismo; Epicurismo; Cristianismo; Ressurreição.

\section{ABSTRACT}

This article aims to show the possible grounds in which the stoic and epicurious philosophers didn't accept the notion of resurrection by Apostle Paul in his speech at the areopagus, described by Luke in the Acts of the Apostles book.

KEY-WORDS: Stoicism; Epicureanism; Christianism; Resurrection

\section{Introdução}

Uma reflexão sobre o encontro que a filosofia teve com o cristianismo primitivo deve, necessariamente, ser feita a partir de uma análise do período em que essas duas visões de mundo tiveram contato. Esse lapso de tempo ficou conhecido como Período Helênico. Sem entrar em questões historiográficas ambíguas, o período helenístico pode ser circunscrito a partir da morte de Alexandre, o Grande, 323 a.C. estendendo-se até a tomada do Egito pelo Império Romano no ano 30 a.C. (GRANDE ENCICLOPÉDIA BARSA, vl. 7, 2004, p. 341 e 342). Todavia, foi no Império Romano, influenciado pela cultura helênica, que o cristianismo teve uma aproximação com essa cultura.

O cristianismo nasceu dentro de uma nação dominada pelo Império Romano. Por isso, a inevitável aproximação. Como exemplo da influência exercida pela cultura helênica sobre o cristianismo, é possível perceber as raízes helênicas sendo ramificadas por meio da língua grega compondo o principal texto da cristandade, o Novo Testamento. O Novo Testamento foi escrito com o grego koinê, idioma desenvolvido no contexto helênico (JEAGER, 2001, p. 17). A influência, portanto, é claramente perceptível e inegável.

\footnotetext{
${ }^{1}$ Professor de Filosofia na Rede Privada. Pesquisador na Área de Filosofia Clássica, Cristã e Metafísica
} 
Entretanto, se o primeiro livro do Novo Testamento foi composto possivelmente no ano 49 d.C. (GUNDRY, 1998, p. 430), então o helenismo com o qual os autores cristãos tiveram contato foi o advindo das interpretações romanas, e não o helenismo clássico, já que este encontra-se por volta do século IV a.C. Portanto, o helenismo com o qual o cristianismo teve contato foi um helenismo mais ético e político, desenvolvido, posteriormente, por duas escolas citadas nos escritos do Novo Testamento, a escola epicúrea e a estoica.

Este artigo pretende, de forma introdutória e panorâmica, analisar o pensamento epicurista e estoico destacando seus principais fundamentos filosóficos. Em seguida, explorar o texto neotestamentário no qual é narrado o encontro de um apóstolo, especificamente Paulo, com os filósofos no areópago ateniense. Por último, destacar alguns possíveis motivos pelos quais esses filósofos rejeitaram a ideia da ressurreição apresentada pelo apóstolo nesse encontro. Para essa análise, o presente artigo utilizou dois textos fundamentais, a saber "Vidas e Doutrinas Dos Filósofos Ilustres” e a Bíblia na Nova Versão Internacional, brevemente apresentados a seguir.

O livro “Vidas e Doutrinas Dos Filósofos Ilustres”, de Diôgnes Laêrtios apresenta de forma concisa o pensamento das escolas epicurista e estoica (entre outras). Pouco se sabe sobre Diôgenes Laêrtios, mas o que a maioria dos estudiosos admite é que ele viveu no século III (Mario da Gama Kury in DIÔGENES LAÊRTIOS, 2008, p. 5). Sua intenção ao escrever essa obra foi “apresentar os principais pensadores gregos, tanto os 'sábios' mais antigos quanto os filósofos propriamente ditos.” (Ibid. 2008, p. 6). Por isso, a relevância desse autor na compreensão do pensamento dessas escolas helênicas, já que muitos dos autores não escreveram seus pensamentos ou tiveram suas obras perdidas, sobrando assim, apenas fragmentos ou citações de outros sobre eles.

A versão bíblica para a análise da narrativa do encontro entre Paulo e essas escolas filosóficas será a Nova Versão Internacional da Bíblia. Essa versão foi escolhida devido a duas qualidades, a saber: clareza na tradução e fidelidade aos melhores manuscritos. A partir dessas fontes será possível entender o pensamento de ambos e distinguir possíveis motivos para a não aceitação da temática da ressurreição.

\section{Pensamento Epicúreo}

Epicuro nasceu em Samos por volta de 341 a.C. Era filho de Neoclés e Cairestrate. Teve seu primeiro contato com a filosofia aos quatorze anos (DIÔGENES LAÊRTIOS, X, 1). Posteriormente, ao tornar-se mestre, fundou uma escola que levava seu nome e reunia-se com 
seus alunos em um jardim. Pelo fato de encontrarem-se em um jardim particular, eram conhecidos como “os do Jardim” (REALE, ANTISERI, 1990, p. 237). Epicuro dividia a filosofia em três partes: Canônica, Física e Ética (DIÔGENES LAÊRTIOS, X, 29.). A primeira, chamada de "Canônica”, buscava definir um critério para a verdade, ou seja, estabelecia os princípios lógicos do discurso. A Segunda, chamada de “Física”, refletia sobre a constituição do real. A terceira e última era a "Ética", que definia a finalidade do indivíduo (REALE, ANTISERI, 1990, p. 239). A partir dessa conjuntura filosófica, Epicuro vivia e ensinava seus discípulos no jardim, longe das intervenções da política e das perturbações do mundo.

No pensamento de Epicuro, discurso, natureza e vida se entrelaçam no indivíduo, como afirma Markus Figueira: “A realidade do pensamento epicúreo reside na associação do pensamento contemplativo ao exercício prático do existir.” (SILVA, 1994, p. 102). Nesse sentido, a filosofia epicúrea torna-se efetivamente palpável, indo além das reverberações da razão por meio do discurso. A filosofia é viva e natural. Por isso, o critério para determinar uma verdade em um discurso sobre algo não é a razão, mas a percepção das sensações (DIÔGENES LAÊRTIOS, X, 31).

Na carta a Herôdotos, Epicuro vai expor seu pensamento concernente a constituição da natureza estabelecendo que está é o “todo”, e esse “todo” é composto de corpos e vazio (Ibid. X, 39). Esses corpos são compostos por átomos indivisíveis e imutáveis (Ibid. X, 41), segue-se daí, que são percebidos pelos sentidos. É clara a relação entre a forma como é possível apreender a verdade, pelas sensações, e a constituição da própria natureza física, composta por corpos formados por átomos e vazio, os quais são percebidos também pelos sentidos. Sendo assim, o critério é o mesmo para a verdade e para a natureza, as sensações.

Em outra carta escrita a Menoiceus, o pensador expõe sua ética fundada também nas sensações. De início ele afirma que a própria divindade é física e não transcendente como as religiões afirmam (Ibid. X, 123). Partindo dessa compreensão, ele atesta que a morte não deveria ser considerada pelos sábios ou temida, porque ela não significaria nada para eles (Ibid. X, 124). Por quê? Seguindo seu raciocínio, se os corpos são a junção dos átomos, e tudo o que existe é composto também deles, dessa maneira, pela natureza, então a morte não teria relação alguma com algum destino traçado pelos deuses. Ela seria apenas a separação dos átomos que compõem os corpos, isto é, um fenômeno natural. E qual seria, então, o princípio orientador da existência? Para Epicuro, seria o prazer. Como ele mesmo afirma: “o prazer é o princípio e o fim da vida feliz.” (Ibid. X, 128). Todavia, ele não está reduzindo o princípio da vida feliz a qualquer espécie de prazer. Existe a necessidade de se fazer o cálculo do que seria útil para se 
alcançar o prazer desejado (CORDEIRO, 2017, p. 242), que por sua vez, conduzirá o indivíduo à vida feliz (Ibid. X, 130).

Resumidamente, o pensamento de Epicuro pode ser entendido a partir das noções de sensação, natureza e prazer. Mesmo pensando a filosofia dividida em três áreas, ela é una no existir por meio do que se apreende pelas sensações. É evidente que muitas outras coisas poderiam ser apresentadas, mas, para a finalidade do presente artigo, o exposto é suficiente. A seguir, será apresentado o pensamento estoico.

\section{Pensamento estoico}

A escola estoica ou estoá foi uma escola que surgiu no final do século IV a.C., possivelmente cinco anos após a fundação do Jardim de Epicuro (REALE, ANTISERI, 1990, p. 251). O fundador dessa escola foi Zênon ou Zenão de Cítion. Ele costumava dar lições a seus discípulos andando de um lado para o outro na Coluna Pintada (Poikile Stoá), por isso, sua escola passou a ser chamada de Estoá e seus discípulos estoicos (DIÔGENES LAÊRTIOS, VII, 5). A semelhança de Epicuro, Zenão negava a transcendência e “concebia a filosofia no sentido de uma ‘arte de viver'.” (REALE, ANTISERI, 1990, p. 252).

Para Zenão a finalidade da filosofia era a excelência. Por isso, ao responder ao rei Antígonos ele declara: "Uma natureza nobre, sustentada por exercícios moderados e depois por uma instrução intransigente, chega com facilidade à posse da excelência perfeita.” (DIÔGENES LAÊRTIOS, VII, 8). Filosofia e vida não se separam, disso decorre que, elas estão unidas na coerência da própria existência do indivíduo.

Os discípulos de Zenão, os estoicos, dividem a filosofia em três partes, a saber: Física, Ética e Lógica (Ibid. VII, 39). E, ilustram essa divisão comparando a filosofia a um ser vivo onde "os ossos e os nervos correspondem à lógica, as partes carnosas à ética e a alma a física.” (Ibid. VII, 40). Para estes, assim como os epicúreos, as sensações são fundamentais. Segundo eles, o conhecimento é uma apreensão segura que não pode ser abalada pela razão (Ibid. VII, 47). Nesse sentido, a verdade é a apresentação imediata da realidade (Ibid. VII, 54). Trata-se, portanto, de uma primazia da sensação, da existência, do que é propriamente físico em contraste com outros pensadores que, por sua vez, pensavam a realidade a partir de realidades metafísicas.

Se a filosofia como arte de viver, por meio de exercícios e instrução, leva à excelência, então, como os estoicos definiam a excelência, sendo esta a finalidade da existência? O próprio Zenão definiu a excelência como fim supremo do homem, como um "viver de acordo com a natureza, ou seja, viver segundo a excelência é o fim para o qual a natureza nos guia.” (Ibid. 
VII, 87). O viver de acordo com a excelência é, portanto, evitar as paixões sendo estas contrárias à natureza porque nos fazem perder a razão (Ibid. VII, 110). O sábio, segundo os estoicos, é imune às paixões. Esse estado do sábio é alcançado pela “apatia”, isto é, pela ausência de paixões (Ibid. VII, 117). Essa é uma diferença clara entre os epicúreos e os estoicos. Enquanto os epicúreos buscam os melhores prazeres como finalidade do homem, os estoicos buscam a excelência por meio da ausência das paixões, dos prazeres por considerá-los inferiores.

Os estoicos pensam tomando a physis como princípio. Sua filosofia é fundada a partir da percepção da realidade, resistindo às paixões e buscando a excelência por meio de exercícios e da instrução. Dessa forma, eles alcançam a excelência e ensinam outros a alcançarem. Essas podem ser consideradas as ideias mestras do pensamento estoico.

A partir de agora, será exposto o encontro dessas duas escolas de pensamento com o cristianismo primitivo. Lembrando que o contexto histórico evidencia a versão romana do encontro entre o epicurismo e o estoicismo, e não a versão clássica dessas duas escolas filosóficas com o cristianismo.

\section{O relato de Atos dos Apóstolos}

Passemos agora a ler o relato completo transcrito por Lucas nas páginas do livro intitulado Atos dos Apóstolos, sobre o encontro de Paulo com os filósofos epicúreos e estoicos.

Enquanto esperava por eles em Atenas, Paulo ficou profundamente indignado ao ver que a cidade estava cheia de ídolos. Por isso, discutia na sinagoga com judeus e com gregos tementes a Deus, bem como na praça principal, todos os dias, com aqueles que por ali se encontravam. Alguns filósofos epicureus e estóicos começaram a discutir com ele. Alguns perguntavam: "O que está tentando dizer esse tagarela? " Outros diziam: "Parece que ele está anunciando deuses estrangeiros", pois Paulo estava pregando as boas novas a respeito de Jesus e da ressurreição. Então o levaram a uma reunião do Areópago, onde lhe perguntaram: "Podemos saber que novo ensino é esse que você está anunciando? Você está nos apresentando algumas ideias estranhas, e queremos saber o que elas significam". Todos os atenienses e estrangeiros que ali viviam não cuidavam de outra coisa senão falar ou ouvir as últimas novidades. Então Paulo levantou-se na reunião do Areópago e disse: "Atenienses! Vejo que em todos os aspectos vocês são muito religiosos, pois, andando pela cidade, observei cuidadosamente seus objetos de culto e encontrei até um altar com esta inscrição: AO DEUS DESCONHECIDO. Ora, o que vocês adoram, apesar de não conhecerem, eu lhes anuncio. "O Deus que fez o mundo e tudo o que nele há é o Senhor do céu e da terra, e não habita em santuários feitos por mãos humanas. Ele não é servido por mãos de homens, como se necessitasse de algo, porque ele mesmo dá a todos a vida, o fôlego e as demais coisas. De um só fez ele todos os povos, para 


\begin{abstract}
que povoassem toda a terra, tendo determinado os tempos anteriormente estabelecidos e os lugares exatos em que deveriam habitar. Deus fez isso para que os homens o buscassem e talvez, tateando, pudessem encontrá-lo, embora não esteja longe de cada um de nós. 'Pois nele vivemos, nos movemos e existimos', como disseram alguns dos poetas de vocês: 'Também somos descendência dele'. "Assim, visto que somos descendência de Deus, não devemos pensar que a Divindade é semelhante a uma escultura de ouro, prata ou pedra, feita pela arte e imaginação do homem. No passado Deus não levou em conta essa ignorância, mas agora ordena que todos, em todo lugar, se arrependam. Pois estabeleceu um dia em que há de julgar o mundo com justiça, por meio do homem que designou. E deu provas disso a todos, ressuscitando-o dentre os mortos". Quando ouviram sobre a ressurreição dos mortos, alguns deles zombaram, e outros disseram: "A esse respeito nós o ouviremos outra vez". Com isso, Paulo retirou-se do meio deles. Alguns homens juntaram-se a ele e creram. Entre eles estava Dionísio, membro do Areópago, e também uma mulher chamada Dâmaris, e outros com eles. (ATOS 17. 16 - 34 / NVI)
\end{abstract}

Esse longo relato está registrado no livro neotestamentário chamado Atos Dos Apóstolo. Escrito por Lucas, possivelmente no ano 62 d.C. (KISTEMAKER, 2006, vl. 1, p. 40 e 41). Nele, estão registrados o nascimento e a expansão da igreja cristã por meio dos apóstolos e discípulos que saíram a proclamar a mensagem cristã. Foi nesse contexto (de uma viagem missionária do apóstolo Paulo) que ocorreu o encontro entre o pensamento cristão e o pensamento helenista.

Paulo costumeiramente apresentava a mensagem cristã dentro das sinagogas judaicas e nas praças das cidades. Em uma ocasião como esta, termina encontrando alguns filósofos epicúreos e estoicos que o convidam a apresentar suas ideias diante deles no areópago. Paulo, então, vai ao areópago e nesse lugar encontra um altar com a seguinte inscrição “AO DEUS DESCONHECIDO” e passa a apresentar o Deus cristão como sendo está Divindade desconhecida do areópago.

Sua mensagem consistiu, em primeiro lugar, na apresentação de Deus como criador de todas as coisas e independente do homem. Para corroborar com suas afirmações, Paulo cita dois poetas gregos, Epimênides (600 a.C.) e Aratus (315 - 240 a.C.); ambos escreveram seus poemas em honra a Zeus (KISTEMAKER, 2006, vl. 2, p. 191 e 192). Este último foi discípulo de Zenão o fundador do estoicismo (FERGUSON, 2009, p. 390). Em segundo lugar, afirmar que a divindade, sendo ela transcendente, não pode ser apreendida em uma escultura. Por último, Paulo enfatiza a culpabilidade da raça humana diante de Deus e que ele (Deus) iria julgar o mundo por meio de um homem (Jesus Cristo) a quem ele mesmo designou. Como prova de que Jesus era esse homem a quem Deus havia enviado para julgar o mundo, Paulo declara a todos os ouvintes presentes no Areópago que Deus o ressuscitou dentre os mortos. Essa afirmativa do apóstolo foi, ao que parece, o grande ponto de cisma entre os ouvintes. 
A narrativa termina com alguns zombando, outros dizendo que o ouviriam em outra ocasião e outros, por sua vez, creram na mensagem, juntando-se a ele, como Dionísio e uma mulher chamada Dâmares, além de outros não identificados pelo autor evangélico.

Ao que parece, os filósofos epicúreos e estoicos ouviram o discurso de Paulo e não apresentaram de início nenhuma objeção ao conteúdo proferido. Somente quando o apóstolo menciona a questão da ressurreição é que eles o interrompem. Mas por quais motivos? Essa é a pergunta para a qual serão propostas algumas razões.

\section{Possíveis motivos para a não aceitação da ressurreição pelos Epicúreos e estoicos}

Não é possível apresentar de forma objetiva os motivos pelos quais os filósofos epicúreos e estoicos não aceitaram a noção de ressurreição apresentada pelo apóstolo Paulo, simplesmente porque o relato bíblico não continua. O possível, então, é apresentar algumas razões, em caráter hipotético, a partir do que apresentamos anteriormente como princípios fundamentais dessas escolas filosóficas em contraste com o relato neotestamentário de Lucas. Vale a pena ressaltar que no relato neotestamentário existe três pontos fundamentais a serem destacados, são eles: Deus como Criador independente do homem, Deus como transcendente e a ressurreição de Jesus como critério pelo qual Deus julgaria os homens. Sob esses fundamentos, passemos a estabelecer algumas hipóteses.

Em primeiro lugar, ao tratar Deus como criador de todas as coisas, Paulo estava estabelecendo não penas aquele que deu origem a todas as coisas, mas também aquele que estabeleceu as leis, pelas quais sua criação deveria ser guiada. Portanto, em caso de quebra da lei, haveria consequências. Para os estoicos, Deus é um ordenador do universo e cabe a nós seguir sua vontade (DIÔGENES LAÊRTIOS, VII, 88). Eles também definem Deus como o “demiurgo criador de todas as coisas no processo relativo a matéria” (Ibid., VII, 134), além de afirmarem que “a substância de Deus é o cosmos inteiro e o céu” (Ibid., VII, 148). Em relação a lei, a única a ser seguida pelos sábios é viver segundo a natureza, sendo está a finalidade suprema do homem (Ibid., VII, 86, 87, 88). Segundo os epicúreos, em relação as divindades, eles consideram "a divindade um ser vivo e feliz, de acordo com a noção da divindade impressa em nós pela natureza” (Ibid., X, 123), além de entenderem que, a noção de erro e quebra da lei, consistiria em agir contrário a natureza, pois consideravam que as perturbações da alma tinham origem na crença de que os astros ou a influência deles tinha alguma relação com o destino dos homens, sendo estes pressupostos apenas míticos (Ibid., X, 81). Contrariamente a isso, a ressurreição na teologia neotestamentária é uma esperança futura, para aqueles que se 
arrependeram dos seus erros diante de Deus, de que um dia também ressuscitariam. Existe nesse ponto uma questão a ser observada. A noção de quebra da lei de Deus é totalmente estranha para as escolas epicúrea e estoica. A única lei para essas escolas, como vimos, seria viver de acordo com a natureza. Não há, portanto, uma noção de culpa ou erro (diante de uma divindade) que necessitaria de arrependimento ou reparação. O único erro ou culpa seria não seguir a natureza, que, no caso dos epicúreos, seria buscar os melhores prazeres; e, no caso dos estoicos, não buscar a excelência. Ambas as escolas helênicas não consideram, diante do que foi exposto anteriormente, algum erro intrínseco do indivíduo oriundo da quebra da lei de alguma divindade que os levaria a uma condição de condenação. O único erro seria não seguir a natureza, pois esta determina, através das sensações, a finalidade dos indivíduos e não as divindades. Nesse sentido, a ressurreição torna-se, na melhor das hipóteses, desnecessária, não havendo culpa ou erro a ser reparado, ou ainda, uma esperança de redenção. Talvez, por isso, os filósofos no areópago não entenderam a noção de ressurreição.

Um segundo motivo da não aceitação da noção de ressurreição pelos filósofos helênicos seria por causa do entendimento judaico-cristã de que Deus é transcendente, ou seja, diferente, superior e totalmente outro em relação a sua criação. Essa noção está presente no discurso de Paulo no areópago ateniense. Como já mencionamos, os estoicos partiam do pressuposto de que as divindades eram parte do cosmo, o cosmo ou ainda os próprios seres vivos (Ibid., VII, 123 e 148). Para os epicúreos, as divindades não teriam qualquer relação com a realidade (Ibid., X, 77, 77, 78), e em caso de existirem, elas também seriam seres vivos (Ibid., X, 123). Sendo assim, percebe-se que a visão dos filósofos helênicos em relação a divindade é diametralmente oposta a visão judaico-cristã. Paulo estava declarando a transcendência do Deus cristão, enquanto aqueles que o ouviam entendiam que as divindades seriam materiais e, portanto, completamente acessíveis a razão natural. O entendimento de uma divindade superior e distinta da realidade, mas que também intervisse na realidade era completamente estranho para esses filósofos.

Em último lugar, temos a ressurreição de Jesus como motivo principal para a não aceitação dessa perspectiva pelos filósofos helênicos. No discurso, Paulo não chega nem a finalizá-lo, efetivamente. O relato termina de forma abrupta, quando é mencionado a questão da ressurreição. O ponto de vista estoico, nos leva a crer que eles não aceitaram o discurso de Paulo sobre a ressureição porque isso não seria natural, não seguiria “o curso suave da vida... ou do que é conforme a natureza.” (Ibid., VII, 88). Já o ponto de vista dos epicúreos, a não aceitação por parte de alguns da mensagem de Paulo, possivelmente se deve ao fato de que eles consideravam que a morte não era nada, por isso, os sábios não deveriam considera-la (Ibid., 
$X, 124)$, além de que eles não se preocupavam com a vida após a morte, já que a alma é corpo, ou seja, composta de átomos, depois da morte a alma se desfaria naturalmente e em relação a alguma culpa ou consequências posteriores a vida, não os preocupavam, pois não tinham essa compreensão (Ibid., X, 63, 125). Sendo assim, na ótica cristã, a ressurreição, em última instância, seria o retorno à vida de um corpo que havia anteriormente padecido. Contudo, tanto os epicúreos quanto os estoicos entendiam que a vida, o corpo, a alma e todas as coisas eram formadas de átomos. E a morte seria a desassociação dos átomos, não havendo mais vida ou o retorno a ela. A vida existe enquanto há associação e interação entre os átomos, pensam eles. A morte é, portanto, a separação dos átomos, não havendo mais interação que produzem reações e percepções. Dessa forma, os átomos não poderiam retornar e formar o mesmo composto anterior, pois a morte é algo natural e o retorno dos átomos a sua forma anterior seria antinatural. É nesse contexto que a ressurreição soa aos ouvidos dos helênicos como no mínimo uma loucura, ou uma impossibilidade natural. Por isso, eles não aceitaram a mensagem de Paulo.

Além disso, conforme apresentado por Paulo, a ressurreição é uma esperança futura, impalpável, apenas aguardada pelos que acreditam e depositam suas esperanças nessa verdade. Os epicúreos e os estoicos não pensam assim, pois seus olhares estão voltados para o corpo, o físico, o naturalmente produzido, o material.

Esses seriam, portanto, os motivos pelos quais alguns filósofos epicúreos e estoicos não aceitaram a noção cristã da ressurreição apresentada pelo apóstolo Paulo em seu discurso no areópago. Todavia, para a cristandade, a ressurreição é uma questão fundamental, como afirma Paulo em sua primeira carta à igreja da cidade de Corinto: "Se não há ressurreição dos mortos, então nem mesmo Cristo ressuscitou; e, se Cristo não ressuscitou, é inútil a nossa pregação, como também é inútil a fé que vocês têm.” (1 Coríntios 15. 13, 14 - NVI).

\section{Conclusão}

Seja por questões morais, físicas ou transcendentais a noção de ressurreição é um ponto de distinção e separação entre a filosofia helênica e o cristianismo. Trata-se de uma questão de princípio fundamental para a cristandade e uma questão no mínimo irrelevante para as escolas filosóficas aqui analisadas. Todavia, existe alguns pontos de encontro entre essas escolas e a fé cristã, principalmente tratando-se da escola estoica concernente a apatia diante das paixões. Em relação à escola epicúrea, poderíamos apresentar, como ponto de contato, a busca do prazer, pois na teologia cristã admite-se a ideia de que o homem busca em várias coisas satisfazer-se, mas só podendo encontrar satisfação plena em Deus e não nas paixões. 
Essas influências podem ser percebidas não apenas nesse breve contato analisado aqui. Se a presente análise fosse estendida, iríamos encontrar a influência da cultura helênica em vários lugares desde a tradução do Antigo Testamento encomendada por Alexandre, o grande, em grego koinê, à forma epistolar como os apóstolos escreveram suas recomendações as igrejas presentes nas cidades, até os conceitos de logos, ekklesia, etc. Contudo, as formas de pensar o mundo apresentam diferenças marcadas e objetivos que precisam ser esclarecidas. Sem eles torna-se impossível o seu entendimento adequadamente.

Vários pontos foram apenas mencionados brevemente devido ao objeto do artigo. Outras análises mais detalhadas de alguns pontos podem ser posteriormente exercitadas. Entretanto, para uma apresentação do discurso neotestamentário e das escolas filosóficas que os escritores canônicos tiveram contato, esse breve artigo proporcionou uma visão panorâmica e introdutória para futuros aprofundamentos.

\section{REFERÊNCIAS}

CORDEIRO, Lucas de Oliveira. Felicidade e prazer em epicuro: uma análise lógica. Revista Lampejo, Vol. 6, $\mathrm{N}^{\circ}$ 2. P. 240 - 245, 2017. Disponível em: http://revistalampejo.apoenafilosofia.org/?page_id=1346. Acessado em: 13 de Fevereiro de 2019.

FURGUSON, Sinclair B. (Org.). Novo Dicionário de Teologia. São Paulo: Hagnos, 2009. GRANDE ENCICLOPÉDIA BARSA. vl. 7, $3^{\text {a }}$ ed. São Paulo: Barsa Planeta Internacional, 2004.

GUNDRY, Robert H. Panorama do Novo Testamento. Tradução João Marques Bentes. São Paulo: Vida Nova, 1998.

JAEGER, Werner. Cristianismo Primitivo e Paideia Grega. Tradução Teresa Louro Pérez. Lisboa: Edições 70, 2001.

KISTEMMAKER, Simon. Comentário do Novo Testamento: Atos. vl. 1. Tradução de Ézia Mullins e Neuza Batista da Silva. São Paulo: Cultura Cristã, 2006.

Simon. Comentário do Novo Testamento: Atos. vl. 2. Tradução de Ézia Mullins e Neuza Batista da Silva. São Paulo: Cultura Cristã, 2006.

LAÊRTIOS, Diôgenes. Vidas e Doutrinas Dos Filósofos Ilustres. Tradução do grego Mário da Gama Kury. Brasília: Editora Universidade de Brasília, 2008.

SILVA, M. F. . Sabedoria e Jardim. Revista Princípios (UFRN. Impresso) , v. 1, p. 101-108, 1994. 